\title{
Group Response to Change for eService Development in Public Sector
}

\author{
Chowdhury Hossan, Nicola McNeil, and Taimur Sharif
}

\begin{abstract}
This paper tests whether there are any significant differences between the level of eService development in the councils and its impact on the organisation across the organisational, individual, and eService utilisation factors. A questionnaire survey among four city council employees in Melbourne, Australia has been conducted. The final result of MANOVA analyses are interpreted in light of Lewin's (1951) model. The findings show that higher role clarity, better job impact, and more positive attitude are found in the embryonic group of city councils that experiences comparatively lower developments in eServices. Furthermore, compared to councils where little change is occurring, the developing group of city councils report less available support. The embryonic group of city council experiences continuity and that is why employees feel more comfortable and familiar with their website.
\end{abstract}

Index Terms-EGovernment, Change management, Australia, public sector.

\section{INTRODUCTION}

Only a few of organisational change efforts do achieve success [1]. Around 70 per cent of all change programs initiated report a failure of the change effort [2]. Building on the early work of Lewin [3], processual theories of organisational change focus on the ways organisations experience change through various phases. Lewin [3] poses a 'three-step' model of planned change management, which consists of a 'freezing', 'moving' and 'refreezing' stage. Lewin [3] suggests that to manage change processes, an organisation must 'unfreeze' their current state into neutral position so that old behaviour can be unlearned and new behaviour can be successfully adopted. Then change should be implemented by utilising driving forces and minimizing resisting forces. One of the key arguments of Lewin [4] is that human behaviour change, whether at the individual or group level, is a psychological, dynamic process that varies at the different stages of organisational development. Lewin's [4] planned approach to change is used to investigate eService related change management in the city councils. For assessing eService benefits, future studies should make a linkage between the benefits of eService and stages of eService development [5]-[7]. Given the multilevel nature and scope of eService adoption and acceptance, future studies should examine interdependencies and non-linear

Manuscript received February 5, 2013; revised April 8, 2013.

C. Hossan is with the College of Business Administration, Abu Dhabi University, UAE (e-mail: chowdhury.hossan@adu.ac.ae).

N. McNeil is with the Department of Management, La Trobe University, Australia (e-mail: n.mcneil@latrobe.edu.au).

T. Sharif is with the Business Administration Department, Alhosn University, UAE (e-mail: taimur.sharif@yahoo.com). relationships that exist between individual, organisational and performance related factors [8]. There are different degrees of eService development among the city councils of Australia [9]. The subsequent sections consider whether there are any significant differences between the level of eService development in the councils and its impact on the organisation across the organisational, individual, and eService utilisation factors. The final result of MANOVA analyses are interpreted in light of Lewin's [4] model.

\section{RESEARCH METHOdOLOGY}

The sample consists of respondents from four city councils around Melbourne metropolitan area in Australia. The respondents in this study are knowledge workers and are administrative employees. These respondents have full-time employment with the council and have some form of decision-making capacity in their job and are direct users of computers with internet access for their daily work. The number of employees in each city council that fall within this category ranges from 210 to 275 . City councils covered in this study were selected using non-probability, purposive sampling. Data collection involves internet-based surveys. This study was interested only in collecting data from employees who have access to a network computer at their work in the council. Thus, an internet-based survey was the most attractive method of data collection [10]. The questionnaire survey was conducted from April to August 2009. Respondents were given a period of three weeks to complete the questionnaire. 515 respondents completed the survey, which equates to a response rate of approximately 52 percent.

MANOVA is appropriate when examining group differences with two or more dependent variables that are correlated [11]. MANOVA provides insights into the nature and predictive power of the independent measures and also highlights the interrelationships and differences seen in the set of dependent measures [12]. For this purpose, four city councils in Australia have been divided into two treatment groups. Three separate MANOVA analyses have conducted to detect differences between two treatment groups in individual, organisational and eService utilisation factors. These two treatment groups indicate the degree of development in providing eServices. Councils with experiencing changes in eService development are undergoing change due to the adoption of comparatively advanced levels of eServices. Councils with continuity in terms of work practices experience a relatively basic level of eService development. Three 2 X 2 multivariate analysis of variance (MANOVA) were conducted to assess group 
differences. Two treatment groups of city councils (or independent variables) were created from reviewing respective council's website, based on their level of sophistication in providing eServices (for further elucidation, see Hossan et al [9]). One group is called Developing Group with two city councils that have high sophistication of eService on their website. The other group is called Embryonic Group with also two city councils that have low sophistication of eService on their websites. Moreover, there are continuity and change relationships active between these two groups. The developing group of city councils experiences comparatively more changes in eServices. Thus, the, continuity of traditional work practices (such as offline or face-to-face transactions) are affected. In contrast, the embryonic group of city councils experiences more continuity in traditional work practices and experiencing fewer changes in eServices.

\section{RESULTS AND DISCUSSION}

\section{A. Differences in Individual Factors among Employees}

The first MANOVA assesses the mean differences between the two groups of city councils on three individual level factors: job impact, attitude, and role clarity. The Impact of Job is defined as the short-term perceived consequences of adopting eServices, and measures the extent to which an employee believes that adopting eServices will enhance their immediate performance. The Attitude towards eServices construct examines an employee's personal feeling or emotional state of mind about the introduction of new work practice involving eServices in the council. The Role Clarity construct examines the level of awareness an employee has regarding the compatibility of changing roles and responsibilities between traditional and new work practices involving eServices. Table I illustrates the descriptive statistics for the MANOVA analysis.

TABLE I: DESCRIPTIVE STATISTICS FOR THE INDIVIDUAL FACTORS FOR CITY COUNCILS GROUPS

\begin{tabular}{lcccc}
\hline \hline $\begin{array}{l}\text { Individual } \\
\text { Variables }\end{array}$ & $\begin{array}{c}\text { City } \\
\text { council } \\
\text { groups }\end{array}$ & Mean & $\begin{array}{c}\text { Standard } \\
\text { Deviation }\end{array}$ & $\begin{array}{c}\mathrm{N} \\
\text { (Employe } \\
\text { es in each } \\
\text { group) }\end{array}$ \\
\hline Job Impact & Developing & 3.6272 & 1.05576 & 152 \\
Attitude & Embryonic & 3.7356 & 0.85089 & 210 \\
& Developing & 3.8544 & 0.92787 & 152 \\
Role Clarity & Embryonic & 4.0055 & 0.83147 & 210 \\
& Developing & 3.2411 & 0.94369 & 152 \\
& Embryonic & 3.5794 & 0.88821 & 210 \\
\hline
\end{tabular}

(Wilks' Lambda $=.965$; Approximate $F=4.26 ; d f=358 ; P=.006$ )

Table I provides a summary of the group profiles on each of the Individual factors across the two groups (developing versus embryonic city councils). The result for the MANOVA indicates a significant overall difference between the two groups of city councils. The embryonic group of city council has the higher mean score on each of the Individual factors. The findings show that higher role clarity, better job impact, and more positive attitude are found in the embryonic group of city councils that experiences comparatively lower developments in eServices. There has not been a significant development in eServices in the embryonic group of city councils. So, these employees reported that their job is essentially unchanged. In general, the city councils do not experience fast-paced change processes. So, workers may carry out the same job, with the same demands, for prolonged periods of time [13]. However, there has been an overall fall in the mean score of role clarity when there have been some developments in eServices. These councils are beginning to change for adopting eService. This developing change is beginning to impact on the way employees see their jobs, and the demand s associated with their job. So in fact, the job demands and skill needs are starting to change, making roles and responsibilities less clear. So the roles are not as clear to employees in the developing group of city councils as it is in the embryonic group of city councils, which has experienced fewer changes in eServices.

\section{B. Differences in Organizational Factors among Employees}

The second MANOVA assesses mean differences between the two groups of city councils on four Organisational level factors: organisational support, leadership support, need for training support and organisational preparedness. Organisational Support measures the extent to which an employee's supervisors, colleagues, peers encourage the adoption of eServices in the council. The Leadership Support construct measures the extent of support an employee receives in their business unit to adopt eServices. The Need for Training Support construct examines the extent of support an employee receives for adopting eServices at the organisational level. The Organisational Preparedness construct measures the extent of presence of common organisational factor within city councils to enable eService development.

TABLE II: DESCRIPTIVE STATISTICS FOR THE ORGANISATIONAL FACTORS FOR CITY COUNCILS GROUPS

\begin{tabular}{lcccc}
\hline \hline \multicolumn{1}{c}{$\begin{array}{c}\text { Organisational } \\
\text { Variables }\end{array}$} & $\begin{array}{c}\text { City } \\
\text { council } \\
\text { groups }\end{array}$ & Mean & $\begin{array}{c}\text { Standard } \\
\text { Deviation }\end{array}$ & $\begin{array}{c}\mathrm{N} \\
\text { (Employe } \\
\text { es in each } \\
\text { group) }\end{array}$ \\
\hline Organisational & Developing & 2.7882 & 0.93657 & 147 \\
Support & Embryonic & 3.1965 & 0.94816 & 210 \\
Leadership & Developing & 2.9259 & 0.95760 & 147 \\
Support & Embryonic & 3.3413 & 0.85992 & 210 \\
Need for Training & Developing & 3.2616 & 0.78941 & 147 \\
Support & Embryonic & 3.6300 & 0.75870 & 210 \\
Organisational & Developing & 3.6698 & .87212 & 147 \\
Preparedness & Embryonic & 4.0847 & .77209 & 210 \\
\hline
\end{tabular}

(Wilks' Lambda=.925; Approximate $F=7.185 ; d f=352 ; P=.000$ )

Table II provides a summary of the group profiles on each of the Organisational factors across the two groups (developing versus embryonic city councils). The results of the test between subject effects shows that organisational support, leadership support, need for training support, and organisational preparedness are all statistically significant These variables detect the success or otherwise facilitate organisational changes. If an organisational change is to be successful, it must be supported by organisation, leadership, training and organisational preparation. The developing group of city councils, which has some organisational change 
for eServices, have lower mean for organisational factors compared to the councils where little change is occurring. This implies the greater change will result in greater need for organisational support and preparation. The embryonic group of city councils has a higher mean score in all four variables compared to the developing group of city councils. These implies employees in the embryonic group of city councils are satisfied with the current level of organisational support, leadership support, need for training support and organisational preparedness, compared with other group. This may be because the developing group of city council is experiencing more changes, due to the introduction and development of eServices. In other words, some changes in eServices are occurring in the developing group of councils. There is a perception among respondents that support for eService in developing group of city councils is less than embryonic group of city councils. It may also be that respondents in developing group of city councils perceived they need more support to cope with real eService developments. Respondents may also perceive that current level of leadership support is not sufficient for the degree of changes occurring. This may be due to the fact that as change takes place in the organisation, additional organisational support, need for training support and more leadership support become essential. With regard to the organisational preparedness, the developing group of city councils exhibits a lower mean score. This suggests that as eService related change is occurring, the perceived level of organisational preparedness is lower the developing group of city councils in compared to embryonic group of city councils. However, compared to councils where little change is occurring, the developing group of city councils report less available support. A possible interpretation is that developing group of city councils requires more organisational support, leadership support, need for training support, and organisational preparedness whilst developing and implementing eService programs. Whereas, in embryonic group of city councils, employees perceiving current level of support is sufficient, since there is not enough challenges for them in terms of eService development. The reported level of leadership support and need for training support is higher in the embryonic group of city councils. Organisational preparedness is higher because not much change is occurring. However, when embryonic group of city council begins to develop eServices and such changes gain momentum, it is anticipated that existing levels of organisational support, leadership support, need for training support and organisational preparedness may not be sufficient to support the change process.

\section{Differences in eService Utilisation Factors among Employees}

The final MANOVA assesses the differences between two groups of city councils on three eService Utilisation (Performance related) factors client impact, end-user value, and usage of website for decision making. The Client Impact construct examines the perception of an employee towards the level of sophistication that eServices should offer to capitalise on the full potential for the external stakeholders such as rate payers, residents and other customers of a council. The End-User Value construct in this study examines the extent to which an employee believes the long-term consequences of eServices for the internal users (employees) will result in gaining improved operational efficiency in operation. The usage of website for decision making construct measures the extent of an employee's engagement with new work practices involving eServices and works as an indication of an individual's intention to adopt eServices.

TABLE III: DESCRIPTIVE STATISTICS FOR THE ESERVICE UTILISATION FACTORS FOR CITY COUNCILS GROUPS

\begin{tabular}{lcccc}
\hline \multicolumn{1}{c}{$\begin{array}{c}\text { Utilisation } \\
\text { Variables }\end{array}$} & $\begin{array}{c}\text { City } \\
\text { council } \\
\text { groups }\end{array}$ & Mean & $\begin{array}{c}\text { Standard } \\
\text { Deviation }\end{array}$ & $\begin{array}{c}\mathrm{N} \\
\text { (Employe } \\
\text { es in each } \\
\text { group) }\end{array}$ \\
\hline Client Impact & Developing & 5.6827 & 0.83575 & 161 \\
End User & Embryonic & 5.5231 & 1.04241 & 225 \\
& Developing & 4.7755 & 0.85060 & 161 \\
$\begin{array}{l}\text { Usage of Website } \\
\text { for Decision }\end{array}$ & Embryonic & 4.5512 & 0.86702 & 225 \\
Making & Embryonic & 3.6290 & 0.80504 & 225 \\
\hline
\end{tabular}

(Wilks' Lambda $=.896$; Approximate $F=14.778 ; d f=382 ; P=.000$ )

Table III provides a summary of the group profiles on each of the eService Utilisation factors across the two groups (developing versus embryonic group of city councils). The results for the MANOVA indicate a significant overall difference between the two groups of city councils. The end-user and usage of website for decision-making constructs measure the direct impact of eServices on the employee's job; these constructs are statistically significant So the End User and Usage of Website for Decision-Making are significant discriminator between two groups. The mean scores End User is higher for the developing group of city councils, which exhibit some development in eServices initiatives. However, the mean score for Usage of Website for Decision-Making is lower for these councils. As there is some eService related change and development within the developing group of city councils, the employees can perceive the impact. For instance, they perceive increase amount of variety in their job, enhanced efficiency, increased quality and effectiveness in their job due to the eService developments. There is also an impact on the End User in developing group of city councils due to eService developments. For example, respondents perceive the council's website to be a good source of feedback - the first port of call and having complete information avoid a number of phone calls - compared with the embryonic group of city council. The embryonic group has a higher mean score than the developing group of city council in the Usage of Website for Decision-Making construct. The embryonic group of city council experiences continuity and that is why employees feel more comfortable and familiar with their website. They report more influence on the usage of website for decision-making because of the continuity in traditional work practices. The embryonic group of city council is carrying out work in a familiar way, using established processes and procedures. But, when change begins to occur, more support will be required. Employees may not feel same level of autonomy and engagement. In fact, there is an overall drop in 
mean score in the Usage of Website for Decision Making since both groups are expecting some degree of eServices development. As councils become increasingly sophisticated in eServices development and implementation, more organisational support will be needed.

\section{CONCLUSION}

The aim of this analysis is to test of the hypothesis that the degree of development of eServices across the city councils is related to the Organisation, Individual and Utilisation factors. Teicher et al. [14] report that the impact eServices on jobs, such as an increase efficiency through eService is perceived to be very low by council employees. The current research findings show a significant difference in role clarity across the two groups. Employees of embryonic group of city councils have better understanding about their roles in job, because the councils experience a relatively minimal and slow-paced change process. In contrast, employees of the developing group of city councils report less role clarity, compared to the reported levels of role clarity reported by the employees of embryonic group of city councils. Change is beginning to impact on the way these employees carry out their tasks and also may require new skills to carry out their new, technology-based work practices. These results demonstrate that employees in the developing group of city councils are more in need of organisational support, such as training and leadership support. These employees require more leadership and organisational support, increased levels of training and their organisations need to be better prepared for eService. These findings are consistent with the organisations that are going through an unfreezing stage of the planned change process [15]. In comparison, employees of embryonic group of city councils are more satisfied with the level of organisational, leadership, need for training support and organisational preparation for eService. The changes in embryonic group of city councils due to the implementation of eServices are relatively minor and have little impact on their traditional work practices. As a consequence, employees are satisfied with current level of support or yet to realise a need for further support for eService implementation in their council. To maintain the current level of espoused satisfaction, embryonic group of city councils should prepare to focus on organisational and leadership support, increased training and organisational preparedness with their progress towards an advanced level of eServices [15]. This implies that the developing councils need to increase organisational and leadership support, levels of training and organisational preparedness in order to maintain their lead in eService implementation. The developing group of city councils anticipates the value to the end-user more clearly than embryonic group of city councils. This is consistent with the idea that information technology becomes more valuable with increased usage [16]. For example, the availability of email would be less important to someone who has never used before, compared with someone who uses email on a regular basis. Since embryonic group of city councils have less eServices sophistication, the end-users are less apparent to these councils. Interestingly, a previous study also found that local governments employees have put little effort into understand client impact [17]. The embryonic group of city councils will have better understanding of the value to the end-users of using eServices when they develop more advanced levels of eService initiatives. An earlier study by Teicher and Dow [18] finds that managers in city councils consider that the eService have a very positive impact on citizens. However, the contribution of eService in usage of website for decision-making is lower in the developing group of city councils. Developing group of city councils have entered into unfreezing stage of change management process associated with eService implementation. It will take time before employees will be able to integrate eServices into their regular work practices [15]. In contrast, the embryonic group of city councils is more comfortable in the usage of website for decision-making, since employee's tasks are based traditional work practices and these employees experience continuity in their job practices. However, both groups of city councils are experiencing an overall drop in the usage of website for decision-making construct, since relatively little degree of change is occurring in both groups. The result shows the value to end-users and usage of website in decision-making of eServices is statistically significant. Even after a decade of eService implementation in Australia, city council employees are yet to truly understand the impact of eServices on their clients. Since employees are increasingly relying on technology for regular work practices, they begin to understand the significance of end-user value and usage of website in decision making eService in their job. The findings suggest that with the development of eServices and better organisational support, employees will increase their utilisation of eServices.

\section{REFERENCES}

[1] J. Kotter, "Leading change: Why transformation efforts fail," Harvard Business Review, vol. 73, no. 2, pp. 59-67, 1995.

[2] J. Balogun, and V. H. Hailey, Exploring Strategic Change, 2nd edition, London: Prentice Hall, 2004.

[3] K. Lewin, "Frontiers in group dynamics," in Field Theory in Social Science, D. Cartwright, Ed. London: Harper and Row, 1947.

[4] K. Lewin, Field Theory in Social Science,' New York: Harper and Row, 1951.

[5] M.P. Gupta, and D. Jana, "E-government evaluation: A framework and case study," Government Information Quarterly, vol. 20, issue 4, pp. 365-387, 2003.

[6] M. J. Moon, “The Evolution of E-Government among Municipalities: Rhetoric or Reality?" Public Administration Review, vol. 62, no. 4, pp. 424-433, 2002.

[7] K. Layne, and J. Lee, "Developing fully functional E-government: A four stage model," Government Information Quarterly, vol. 18, no. 2, pp. 122-136, 2001

[8] R. Titah and H. Barki, "E-Government Adoption and Acceptance: A Literature Review and Research Framework," in E-Government Research: Policy and Management, D. Norris, Ed. IGI Global, 2008, pp. 42-97.

[9] C. G. Hossan, T. Joiner, and D. Brown, "Enhancing eServices in Australian Local Government: The Role of Strategic Leaders and Employee Commitment to Change," in the Proceedings of the 23rd Annual Australian and New Zealand Academy of Management Conference (ANZAM), Melbourne, 2009.

[10] K. Corley and K. Jansen, "Capturing survey data electronically: methodological issues and implications," presented at the Academy of Management Conference, Toronto, 2000. 
[11] K. N. Malhotra, Marketing Research- An applied orientation, $4^{\text {th }}$ ed. India: Pearson education International, 2006.

[12] F. J. Hair, W. C. Black, J. B. Barry, E. A. Rolph, and R. L. Tatham, Multivariate Data Analysis, $6^{\text {th }}$ ed. Upper Saddle River: Pearson Education International, 2006.

[13] N. Marshall, "Introduction: Themes and issues in Australian local government," in Australian Local Government: Reform and Renewal, Dollery, B. and Marshall, N. ed. Melbourne: Macmillan Education Australian Pty Ltd., 1997, pp. 1-14.

[14] J. Teicher, O. Hughes, and N. Dow, "E-government: A new route to public sector quality", Managing Service Quality, vol. 12, no. 6, pp. 384-393, 2002.

[15] E. H. Schein, "Kurt Lewin's change theory in the field and in the classroom: notes towards a model of management learning," Systems Practice, vol. 9, no. 1, pp. 27-47, 1996.

[16] S. Taylor and P. A. Todd, "Understanding Information Technology Usage: A Test of Competing Models," Information Systems Research, vol. 6, no. 4, pp. 144-176, 1995.

[17] J. Burn and G. Robins, "Moving towards e-government: a case study of organizational change processes," Logistic Information Management, vol. 16 , no. 1 , pp. 25-35, 2003.

[18] J. Teicher and N. Dow, "E-government in Australia: Promise and progress," Information Policy, vol. 7, no. 4, pp. 231-246, 2002.

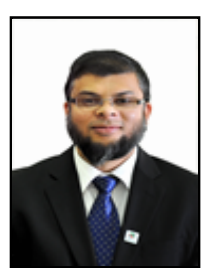

Chowdhury G Hossan was born in Bangladesh. He has obtained $\mathrm{BBA}$ and $\mathrm{MBA}$ in Management from University of Dhaka, Bangladesh in 2000 and 2002 respectively. He has received Master in E-business Management from International University of Japan in 2004. He has earned his PhD in Management from La Torbe University, Melbourne, Australia in 2010.

$\mathrm{He}$ is working as an Assistant Professor of Management at the College of Business Administration, Abu Dhabi University, UAE. Previously, he served as a faculty member of management at the School of Management, La Trobe University, Australia, Ballarat University, Australia, Melbourne Institute of Technology, Australia, and at the East West University, Bangladesh. He also worked as an e-commerce consultant for Peoplink, MD, USA and fellow for Mobile Government Consortium, Brighton, United Kingdom.

Dr Hossan's several research articles on eGovernment and management have been published in national and international reputed journals and in international conferences proceedings. He has received several research grants. He is currently serving as a PhD examiner for New Castle University, Australia. He is also supervising several doctoral candidates in Abu Dhabi University, UAE. He is also reviewer for several international journals and conferences. His research interest includes attitude and productivity, eGovernment, and entrepreneurship. $\mathrm{He}$ can be contacted at hossan@iuj.ac.jp

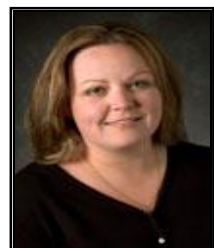

Nicola McNeil is a lecturer in Management at La Trobe University, Melbourne, Australia. She has completed a Bachelor of Commerce [Hons] and a Bachelor of Laws at Monash University and a PhD at Deakin University. Her $\mathrm{PhD}$ studies investigated the effect of new public management reforms in higher education on the strategic activities of Australian Universities. Her current research interests include the implications of new public management reforms, the impact of institutional forces on organisational processes and practices and survey methodologies.

She is the current Treasurer and member of the Executive Management Committee of the Australian Consortium of Social and Political Research Incorporated [ACSPRI].

Dr McNeil is the subject coordinator of the School's first year management subject, and is responsible for the coordination of the School's Honours Program. In 2009, Nicola received a LaTrobe University Citation for Outstanding Contribution to Student Learning.

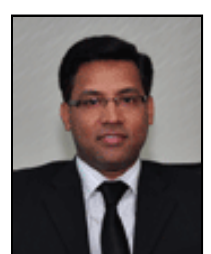

Taimur R. M. Sharif was born in Bangladesh on 28 December 1972. He obtained BA (Hons) \& MA in Economics from Aligarh University (India) in 1994 \& 1996 respectively, MSc in Quantitative Economics from Stockholm University (Sweden) in 1998, MBA in Marketing from Darul Ihsan University (Bangladesh) in 2004 and PhD in International Business from London South Bank University (UK) in 2011. The author also obtained a full British teaching qualification from the University of Sussex (UK) in 2009

$\mathrm{He}$ is currently serving in ALHOSN University (UAE) as a Faculty Member in Business \& Economics. Prior to this, he worked for London South Bank University (UK), 2009-2011, Central Sussex College (UK), 2007-2008, American University-Bangladesh, 1999-2004, among others The author has keen interest in research in the area of public economics, labour economics and technology transfer. He has so far published in ten regional and international journals in economics \& business, and presented papers in UK, Thailand, Indonesia and Bangladesh as keynote speaker. Currently, he has research interest in international HRM.

Dr. Sharif is a member of a number of professional bodies. To mention a few: Institute for Learning (UK), Royal Economic Society (UK) Development Studies Association (UK), European Association for Practitioner Research on Improving Learning (Belgium), European Economic Association (Italy), World Economic Association (UK). Dr Sharif has been a member of the editorial board of AIUB Journal of Business \& Economics since 2002. The author received Commonwealth scholarship (India), awards for excellence (twice) from Notre Dame College (Bangladesh), merit certificates from Darul Ihsan University (Bangladesh) \& Aligarh University (India), among others. 